\title{
DETECTION OF ADULTERATION IN MILK AND SOME DAIRY PRODUCTS
}

\author{
SAADIA H.H SHINAWY ${ }^{1}$; ADEL M. EL-KHOLY ${ }^{1}$; MOHAMED M.A. ZEINHOM ${ }^{1}$ and \\ ALAA Y. GABER ${ }^{1}$ \\ ${ }^{1}$ Department of Food Hygiene, Faculty of Veterinary Medicine, Beni-Suef University, Beni-Suef, Egypt
}

Received: 8 February 2018; Accepted: 28 February 2018

\begin{abstract}
Food adulteration is an act for debasing the quality of food with an admixture or through the substitution of inferior substances or by removing some invaluable ingredients from the food product. A total of 150 random samples of milk and some milk products (30 samples from each of raw cow's milk, UHT milk, Thick cream, Imported butter, Farmers Butter) were collected from different regions of Beni-Seuf city, Egypt and subjected to chemical analysis for detection of various adulterants. This study proved that the most prominent types of adulteration were addition of water, partial skimming or both. On the other hand, preservatives and commercial additives were absent in all milk and cream samples except gelatin which was found in $76.6 \%$ of cream samples. The mean iodine number of the imported butter and farmers butter samples ranged from $39.93 \pm 1.173$ and 37.43 \pm 0.718 , respectively. All examined butter samples were free from cotton seed oil and starch while sesame oil was present in a percentage of $56.67 \%$ and $36.67 \%$ in the examined imported and farmers butter, respectively. In conclusion this qualitative analysis which has unfolded proved that some of milk and milk product procured did not conform to the legal standard and adulterated with some adulterants which decrease their nutritive value and may cause public health hazard.
\end{abstract}

Key words: Milk adulteration, cream, preservatives, commercial additives, iodine number, butter adulteration.

\section{INTRODUCTION}

Milk is a perfect human being food, produced by the mammary glands of mammals with high nutritional value providing the primary source of nutrition for young mammals before they are able to digest other types of food. Fresh milk is considered as a complete diet because it contains the essential nutrients as lactose, fat, protein, mineral and vitamins in balanced ratio rather than other foods (Khalid, 2006).

Cream is one of the most important dairy products defined either according to fat percent or heat treatment. It is considered as a primary product in manufacture of table butter, or for preparing ghee (Standard, 1966), also butter is considered the queen of fat specially when it comes from grass-fed cows, it is a rich source of vitamin $\mathrm{A}, \mathrm{D}, \mathrm{E}$ and $\mathrm{K}$ which are needed for the body and brain health and contain lecithin which assists in the proper assimilation and metabolization of cholesterol and other fat. It may be adulterated with addition of animal body fat hydrogenated oils and sometimes even the non-edible mineral oil (Tanmay et al., 2017).

Corresponding author: Dr. ALAA Y. GABER

E-mail address: vet.alaayehya@gmail.com

Present address: Department of Food Hygiene, Faculty of

Veterinary Medicine, Beni-Suef University, Beni-Suef, Egypt.
Milk is a perishable commodity and is likely to be spoiled during summer season when weather becomes very hot. Also, due to unorganized and nonregulated marketing systems, the quality of milk is hardly maintained at consumer level, the middlemen through adding chemical preservatives such as penicillin, strepto-penicillin, formaldehyde, hydrogen peroxide, sodium bi-carbonate, etc. The adulterants and preservatives assume the proportion of health hazards for the consumers, particularly infants (Tipu et al., 2007; Javaid et al., 2009).

Adulteration of milk is done to increase its volume. Starch and other reconstituted milk powders are added to increase its viscosity. To increase the shelf life of milk ice and some chemicals like hydrogen peroxide, carbonates, bicarbonates, antibiotics, caustic soda and even the most lethal chemical formalin are being used. Urea adulterated milk is very harmful to the girls as it hastens up the process of puberty (Tariq, 2001).

Also, the adulteration of milk deteriorates the quality of milk, and may cause human health hazards, like gastroenteritis, nausea, vomiting, diarrhea, kidney damage and failure, acute failure of circulatory system, asthma, urticaria, metabolic acidosis, and convulsions in sensitive persons (Beall and Scofield, 1995; Mota et al., 2003; Haasnoot et al., 2004; Saad 
et al., 2005; Ayub et al., 2007; Rideout, 2008; Gwin et al., 2009; Zhang et al., 2009; Awan et al., 2014).

So, this study was conducted to determine the chemical composition and detect various adulterants in milk and some milk products available in local market in different regions of Beni-Seuf city, Egypt.

\section{MATERIALS AND METHODS}

1. Collection and handling of the samples:

A total of 150 random samples of milk and some milk products (30 samples of each of raw cow's milk, pasteurized milk, thick cream, Farmers butter, Imported Butter) from different regions of Beni-Seuf city, Egypt during the period from February 2015 to Jan 2016 were collected in a clean, dry and sterile jars, and transferred to the laboratory with a minimum of delay, whereas they directly examined or held in the refrigerator until time is due.

\section{Preparation of samples:}

\subsection{Milk Samples:}

Each milk sample $(500 \mathrm{ml})$ was mixed thoroughly before being divided into 4 sub-samples. The first was used for detection of heat treatment, the second was used for compositional quality evaluation, the third was used for detection of preservatives, and the forth was used for detection of common commercial additives.

\subsection{Cream samples (Standard, 1997):}

Each cream sample $(250 \mathrm{gm})$ was mixed and warmed at temperature $35^{\circ}-40^{\circ} \mathrm{C}$ in a water bath, then the sample was cooled to a room temperature.

\subsection{Butter samples}

Each butter sample (250 gm.) was mixed thoroughly before being divided into 2 sub-samples. The first was used for detection of iodine number, while the second was melted to perform the other tests.

\section{Methods of examination:}

\section{i. Milk and cream samples}

1- Detection of heat treatment: by using Storch's test (Lampert, 1975).

\section{2- Compositional quality evaluation of examined} milk samples.

a. Determination of fat \%: By Gerber method (FAO, 1977).

b. Determination of total solid \% (Ling, 1963).

c. Determination of milk solids not fat \% (Harding, 1995).

d. Determination of added water \% (Ling, 1963).

3. Specific chemical tests for detection of preservatives.

a. Detection of formalin (Panda and Bindla, 1998).

b. Detection of salicylic acid (Ling, 1963).

c. Detection of Hydrogen peroxide (Pien et al., 1953)

d. Detection of boric and borax (ling, 1963).

e. Detection of nitrate (Pond Water) (Sharma and Barui, 2011).

\section{4- Detection of commercial additives:}

1. Detection of starch and cereal flour (Kumar et al., 1998).

2. Detection of urea (Act PFA, 1954).

3. Detection of ammonium sulphate (Kumar et al., 2002).

4. Detection of detergent (Singhal, 1980).

5. Detection of coloring matter (Batis et al., 1981).

6. Detection of gelatin in cream (AOAC, 2000c).

ii. Butter samples

1. Determination of Iodine number (AOAC, 2000a)

2. Detection of sesame oil (Baudouin's Test) (Recioand Olieman, 1996).

3. Detection of cotton seed oil (halphen's test) (AOAC, 2000b).

4. Detection of starch and cereal flour (Kumar et al., 1998).

\section{RESULTS}

Table 1: Statistical analytical results of the examined samples based on fat percentage.

\begin{tabular}{cccccc}
\hline The examined Samples & No of the examined sample & Min & max & mean & \pm SE \\
\hline Rawcow's milk & 30 & 2.00 & 4.00 & 3.01 & 0.098 \\
\hline UHT milk & 30 & 2.50 & 3.50 & 3.10 & 0.058 \\
\hline Cream & 30 & 27.78 & 76.90 & 56.99 & 2.757 \\
\hline
\end{tabular}


Table 2: Statistical analytical results of examined samples based on total solids percentage.

\begin{tabular}{ccccccc}
\hline The examined Samples & $\begin{array}{c}\text { No of the } \\
\text { examined sample }\end{array}$ & Min & max & mean & \pm SE \\
\hline Raw cow's milk & 30 & 8.54 & 11.44 & 10.04 & 0.138 \\
\hline UHT milk & 30 & 9.14 & 10.84 & 10.07 & 0.073 \\
\hline
\end{tabular}

Table 3: Statistical analytical results of examined samples based on solids not fat percentage.

\begin{tabular}{cccccc}
\hline The examined Samples & $\begin{array}{c}\text { No of the examined } \\
\text { sample }\end{array}$ & Min & max & mean & \pm SE \\
\hline Raw cow's milk & 30 & 6.05 & 7.84 & 7.03 & 0.069 \\
\hline UHT milk & 30 & 6.53 & 7.49 & 6.98 & 0.049 \\
\hline
\end{tabular}

Table 4: Correlation between methods for adulteration of milk.

\begin{tabular}{ccccccccccc}
\hline \multirow{2}{*}{$\begin{array}{c}\text { The examined } \\
\text { Samples }\end{array}$} & \multicolumn{3}{c}{ Partial skimmed } & \multicolumn{2}{c}{ Addition of water } & \multicolumn{2}{c}{$\begin{array}{c}\text { Addition of water and } \\
\text { partial skimmed }\end{array}$} \\
\cline { 2 - 10 } & No. & $+\mathrm{ve}$ & $\%$ & No. & $+\mathrm{ve}$ & $\%$ & No. & $+\mathrm{ve}$ & $\%$ \\
\hline Raw cow's milk & 30 & 8 & 26.67 & 30 & 30 & 100 & 30 & 8 & 26.67 \\
\hline UHT milk & 30 & 5 & 16.67 & 30 & 30 & 100 & 30 & 5 & 16.67 \\
\hline
\end{tabular}

Table 5: Statistical analytical results of the examined samples based on detection of some preservatives.

\begin{tabular}{ccccc}
\hline \multirow{2}{*}{ Item } & $\begin{array}{c}\text { No of examined } \\
\text { sample }\end{array}$ & Raw cow's milk & UHT milk & cream \\
\cline { 3 - 5 } & 90 & No of $+\mathrm{ve}$ & No of +ve & No of +ve \\
\hline Formalin & 90 & N.D & N.D & N.D \\
\hline Salicylic acid & 90 & N.D & N.D & N.D \\
\hline Hydrogen peroxide & 90 & N.D & N.D & N.D \\
\hline Boric acid & 90 & N.D & N.D & N.D \\
\hline nitrate & N.D & N.D & N.D
\end{tabular}

N.D $=$ Not detected

Table 6: Statistical analytical results of the examined samples based on detection of some commercial additives.

\begin{tabular}{ccccccccc}
\hline \multirow{2}{*}{ Item } & \multirow{2}{*}{$\begin{array}{c}\text { No of the } \\
\text { examined sample }\end{array}$} & \multicolumn{2}{c}{ Rawcow's milk } & \multicolumn{2}{c}{ UHT milk } & \multicolumn{2}{c}{ cream } \\
\cline { 3 - 8 } & No of +ve & $\%$ & No of +ve & $\%$ & No of +ve & $\%$ \\
\hline Starch & 90 & N.D & 0 & N.D & 0 & N.D & 0 \\
\hline Urea & 90 & N.D & 0 & N.D & 0 & N.D & 0 \\
\hline Ammonium sulphate & 90 & N.D & 0 & N.D & 0 & N.D & 0 \\
\hline Detergent & 90 & N.D & 0 & N.D & 0 & N.D & 0 \\
\hline Coloring matter & 90 & N.D & 0 & N.D & 0 & N.D & 0 \\
\hline Gelatin & 30 & - & - & - & - & 23 & 76.67 \\
\hline
\end{tabular}


Table 7: Statistical analytical results of the examined samples based on their iodine number.

\begin{tabular}{cccccc}
\hline Samples & $\begin{array}{c}\text { No of the } \\
\text { examined sample }\end{array}$ & Min & max & mean & \pm SE \\
\hline Imported butter & 30 & 30.45 & 55.83 & 39.93 & 1.173 \\
\hline Farmers butter & 30 & 30.45 & 44.00 & 37.43 & 0.715 \\
\hline
\end{tabular}

Table 8: Statistical analytical results of the examined samples based on cotton and sesame seed oil and starch.

\begin{tabular}{cccccccc}
\hline \multirow{2}{*}{ samples } & \multirow{2}{*}{$\begin{array}{c}\text { No of the } \\
\text { examined sample }\end{array}$} & \multicolumn{2}{c}{ Baudouin's Test } & \multicolumn{2}{c}{ halphen's test } & \multicolumn{2}{c}{ starch } \\
\cline { 3 - 8 } & & No of +ve & $\%$ & No of +ve & $\%$ & No of +ve & $\%$ \\
\hline Imported butter & 30 & 17 & 56.67 & N.D & 0 & N.D & 0 \\
\hline Farmers butter & 30 & 11 & 36.67 & N.D & 0 & N.D & 0 \\
\hline
\end{tabular}

N.D $=$ Not detected.

\section{DISCUSSION}

Storch's test proved that all samples were randomly collected from dairy shops were in raw state, while all UHT milk samples were exposed for heat treatment. Similar results obtained by El-Bessary (2006) for raw cow's milk and Debnath et al. (2014) for UHT milk, while positive result was obtained by El-Loly et al. (2013) for raw cow's milk. heat treatment of the produced milk may protect consumers from being infected with pathogens, but it masks the unsanitary conditions under which milk is produced so it is act as a common type of adulteration also milk heating may result in off flavors and denaturation of protein (Draaiyer et al., 2009).

The results given in Table 1 indicated that the fat percentage for the examined raw cow's milk samples ranged from 2.00 to 4.00 with a mean value $3.01 \pm$ 0.098, while for UHT milk ranged from 2.50 to 3.50 with a mean value of $3.10 \pm 0.058$, and for thick cream samples it ranged from 27.78 to 76.0 with a mean value of $56.99 \pm 2.757$.

The results were in agreement with those recorded by Mansour et al. (2012) and Amin (2016), while higher values were reported by Hossain et al. (2013) and Debnath et al. (2014), but the lower results were obtained by Sobeih (2000) and Fahmid et al. (2016) in raw cow's milk, while for UHT milk the results were in accordance with those reported by Bendale $e t$ al. (2015), but higher values were reported by Sobeih (2000) and Debnath et al. (2014), while lower values were obtained by Awan et al. (2014).

The low fat content in milk samples may be due to either reduced forage consumption and consequently decreases acetate and butyrate contents in rumen which are the major fat precursors, or to milk obtained after 4-5 lactations (animal's age), or failure in stripping after milking, or attributed to adulteration by addition of water and /or partial skimming (Harding, 1995; Nickerson, 1995).

It is noticed from the obtained data in Table 2 that the total solids percentage for the examined raw cow's milk samples ranged from 8.54 to 11.44 with a mean value of $10.04 \pm 0.138$, while for UHT milk, it ranged from 9.14 to 10.84 with a mean value of $10.07 \pm 0.073$. These findings were significantly lower than the legal minimum of the Egyptian Standard (not less than $11.25 \%$ ) (Egyptian Standards, 2005). The recorded results in raw cow's milk nearly similarly agreed with those reportedby Mansour et al. (2012), while higher value were reported by Sobeih (2000), Fahmid et al. (2016) and Genzebu et al. (2016), but lower results were obtained by Faraz et al. (2013), where as higher values of heat treated milk were reported by Sobeih (2000), and lower values were obtained by Awan et al. (2014).

As shown in Table 3 the solids not fat percentage for the examined raw cow's milk samples was ranged from 6.05 to 7.84 with a mean value of $7.03 \pm 0.069$, while for UHT milk it was ranged from 6.53to 7.49 with a mean value of $6.98 \pm 0.049$, These results do not meet the legal Minimum of Egyptian standard (not less than 8.25\%) (Egyptian Standards, 2005). Nearly similar results in raw cow's milk were reported by Fahmid et al. (2016) and Uddin et al. (2016), while higher value were reported by Sobeih (2000) and Amin (2016), but lower results were obtained by Faraz et al. (2013), while higher results of UHT milk are reported by Sobeih (2000) and Bendale et al. (2015), but lower values were recorded by Awan et al. (2014). The lower SNF content could be attributed mainly to adulteration by addition of water (Harding, 1995) as it decreases only by addition of water and not affected by partial skimming. 
The data summarized in Table 4 mentioned that the water is added in varying degree in all types of milk samples which confirmed adulteration of milk by addition of water, but only about $8(26.67 \%)$ out of 30 raw cow's milk sample and 5 (16.67) out of 30 UHT milk samples were adulterated by partial skimming of milk fat. Finally about $8(26.67 \%)$ out of 30 raw milk samples and 5 (16.67) out of 30 UHT milk samples were adulterated by both addition of water and partial skimming of milk fat. The obtained results were in agreement with Chanda et al. (2012) and Swathi and Kauser (2015) in raw cow's milk and by Shaikh et al. (2013) in UHT milk, while lower results were obtained by Kandpal et al. (2012) and Debnath et al. (2014) for raw cow's milk and by Adam (2009) and Debnath et al. (2014) for UHT milk.

Generally, cow's milk samples had more subjected to adulteration by addition of water than buffalo's milk as it is low in fat content and any partial removal of fat will be appear. So, the retailers are pushed to addition of water to cow's milk than buffalo's milk (Mansour et al., 2012).

It is noticed that water is admixed with whole milk to increase the volume of milk during summer season, to successfully deal with the demand (Afzal et al., 2011). Water may be a source of microorganisms, harmful chemicals and poisonous substances. On the other hand, the addition of water decreases the milk solids not fat contents specially proteins which is very important for normal growth (Moore et al., 2012 and Santos et al., 2013). Also, skimming of fat inhibit the body from utilization of fat andfat-soluble vitamins as $\mathrm{A}, \mathrm{D}, \mathrm{E}$ and $\mathrm{K}$ which are very important for biological processes and normal growth of the body (Kartheek et al., 2011).

The result given in Table 5 indicated that all examined milk samples (raw cow's milk, UHT) and cream samples were free from the tested preservatives. The obtained results for formalin in raw cow's milk is in agreement with Abdel-Hameid (2002), El-Bessary (2006) and Amin (2016) while positive values were obtained by Wahba and Korashy (2006) and Debnath et al. (2014), also in UHT milk the results were similar to those reported by Debnath et al. (2014) and Prodhan et al. (2016), while positive results were obtained by Souza et al. (2011) and Debnath et al. (2015). Formalin causes damages of liver, lung tissues and increasing of total oxidant capacity (Aydin et al., 2015). The gained results for salicylic acid were similar with Wahba and Korashy (2006) and Amin (2016) in raw cow's milk and Lateef et al. (2009) in UHT milk, however Barham et al. (2014 a), Barham et al. (2104 b) recorded the positive results in raw cow's milk and Debnath et al. (2015) in UHT milk. Similar results for Hydrogen peroxide were reported by Debnath et al. (2014), while positive results were recorded by Debnath et al.
(2015) in raw cow's milk and UHT milk. Hydrogen peroxide has adverse effects on antioxidants balance in the human body leading to disturbance in the natural immunity and carcinogenic effect (Clare et al., 2003). The gained results for detection of Boric acid were fair agreement with El-Bessary (2006) and Debnath et al. (2014) in raw cow's milk and with Lateef et al. (2009) and Debnath et al. (2014) in UHT milk, while the positive results of raw cow's milk were recorded by Wahba and Korashy (2006), Mansour et al. (2012) and Amin (2016). Boric Acid causes nausea, vomiting, diarrhea, kidney damage, acute failure of circulatory system and even Death (See et al., 2010).

Result of detection of Nitrate is in fairly close agreement with El-Bessary (2006) in raw cow's milk and Bendale et al. (2015) in UHT milk, but positive results were recorded by Mansour et al. (2012). The overabundance dietary admission of nitrate lead to metahemoglobinaemia and the vivo production of the carcinogenic effect especially newborn infants (Gapper et al., 2004).

It is clearly evident to mention that our samples are free from chemical preservatives, but other residues as antibiotics or sulfa drug residues may be introduced into milk via treatment of dairy animals, their feeds, milking instrument and processing plants (Hubbert et al., 1996).

The results summarized in Table 6 showed that the examined additives couldn't be detected in all milk and cream samples with exception for gelatin that observed in creams sample at a percentage of $23(76.6 \%)$ out of 30 sample, which give it firmness and an appearance of richness (Stokes, 1897).

It is interest to note that the middlemen are added starch to synthetic and natural milk to adjust and or to increase the consistency and viscosity (Mudgil, 2008). Result of detection of Starch seems to be agreement with Debnath et al. (2014) and Uddin et al. (2016) in raw cow's and UHT milk, while positive results were recorded by Swathi and Kauser (2015) in raw cow's milk and Barham et al. (2015) in UHT milk. The adulterated milk with high amounts of starch can cause diarrhea due to the impacting of indigestible starch in colon and accumulation of indigestible starch in diabetic patients may prove very fatal (Singuluri and Sukumaran, 2014).

Addition of urea to milk, making the milk looked thick and concentrated giving a feeling of rich milk while, in fact it was low in fat and SNF and was poisonous due to the presence of excess urea (FAD, 2005 and Renny et al., 2005). The obtained results of detection of urea were agreed with Soomro et al. (2014) and Swathi and Kauser (2015) for raw cow's milk and with Bendale et al. (2015) for UHT milk, whereas the positive results were recorded by 
Kandpal et al. (2012) and Faraz et al. (2013) for raw cow's milk and with Debnath et al. (2014) for UHT milk.

Ammonium Sulphate is a chemical fertilizer, which is added to milk to raise the density of watered milk and increases the lactometer reading by maintaining the density of milk (Abbas et al., 2013). The obtained results for Ammonium sulphate were agreed with Nirwal et al. (2013) in raw cow's milk and Lateef et al. (2009) in UHT milk, but positive results were recorded by Debnath et al. (2015) for raw cow's and UHT milk.

The detergents are added to milk to emulsify and dissolve the oil in water giving the frothy solution (foamy appearance), and give milk its characteristic white color (Centre for science and environment, 2006). Nearly similar results of detection of detergent were reported by Faraz et al. (2013) and Soomro et al. (2014) in raw cow's milk and Awan et al. (2014) in UHT milk, while the positive results were recorded by Debnath et al. (2014) in raw and UHT milk.

Iodine value (IV) is a measure of the extent of unsaturation of fat (Rangappa and Achaya, 1974 and Knothe, 2002). The presented data in Table 7 explained that the iodine number of the examined imported and farmers butter samples ranged from 30.45 to 55.83 with a mean value of $39.93 \pm 1.173$ and 30.45 to 44.00 with a mean value of $37.43 \pm 0.715$, respectively. Our results approximately agreed with those previously achieved by Hallabo and El-Nikeety (1987), for the imported butter, and EL-Mossalami (2014) for farmers butter, while higher results were obtained by EL-Mossalami (2014)for the imported butter and Ibrahim (2006) for the farmers butter, whereas lower results were recorded by Sagdic et al. (2004), for the imported butter and Park et al. (2007) for the farmers butter, it was noticed that the iodine value did not differ significantly from one season to another and the lowering of the iodine values due to lack of green fodder in summer which compensated by administration of sufficient quantity of oil-cakes containing fats of high iodine values. (Kehar, 1956).

The data summarized in Table 8 revealed that 17 $(56.67 \%)$ out of 30 examined imported butter samples and $11(36.67 \%)$ out of 30 examined farmers butter were positive for sesame seed oil while all examined butter sample were free from cotton seed oil and starch. Similar result for sesame seed oil was reported by Parmar (2005), but negative result was obtained by Rao et al. (2004). Positive results for presence of starch were recorded by Swathi and Kauser (2015).

It can be concluded from the present investigation that the milk and dairy product mayexhibit a wide array of hazardous impacts on human health. So in order to protect consumers from the hazards of adulteration. Periodical inspection of markets by inspectors of ministry of health should be enforced to control and to minimize the risks of adulteration and health ministry laboratories facilities need to be supplemented and upgrading to be capable of performing all related tests.

\section{REFERENCES}

Abbas, M.N.; Khattak, B.; Sajid, A.; Islam, T.; Jamal, Q. and Munir, S. (2013): Biochemical and bacteriological analysis of cows' milk samples collected from district peshawar. Int. J. Pharm. Sci. Rev. Res, 21(2): 221-226.

Abdel-Hameid, K.G. (2002): Studies on the sanitary condition of raw milk in Qena Governorate. M.V. Sc. Thesis, Fac. Vet. Med., Assiut Univ., Egypt.

Act, P.F.A. (1954): Prevention of food Adulteration Act and rules. Gov. of India publication as amended up to date.

Adam, A.A.H. (2009): Milk adulteration by adding water and starch at Khartoum state. Pakistan Journal of Nutrition.8 (4): 439-440.

Afzal, A.; Mahmood, M.S.; Hussain, I. and Akhtar, M. (2011): Adulteration and microbiological quality of milk (a review). Pakistan Journal of Nutrition. 10(12): 1195-1202.

Amin, W.F. (2016): Detection of adulteration of raw cow's milk in Assiut City, Egypt. Int. J. Adv. Res. Biol. Sci, 3(12): 160-165.

AOAC (2000a): "Official Methods of Analysis of AOAC International." Association of Official Analysis Chemists International, Official Method 920. 158 Hanus Method.

AOAC (2000b): "Official Method of Analysis of AOAC International." Association of Official Analysis Chemists International, Official Method 197.02 Halphen's test.

AOAC (2000c): "Official Method of Analysis of AOAC International." Association of Official Analysis Chemists International, Official Method 920.106 Gelatin in milk and milk products.

Awan, A.; Nasser, M.; Iqbal, A.; Ali, M.; Iqbal, R. and Iqbal, F. (2014): A study on chemical composition and detection of chemical adulteration in tetra pack milk samples commercially available in Multan Pakistan Journal of Pharmaceutical Sciences. 27(1): 183-186.

Aydin, S.; Ogeturk, M.; Kuloglu, T.; Kavakli, A. and Aydin, S. (2015): Effect of carnosine supplementation on apoptosis and irisin, total oxidant and antioxidants levels in the serum, liver and lung tissues in rats exposed to formaldehyde inhalation. Peptides, 64: 14-23.

Ayub, M.; Ahmad, Q.; Abbas, M.; Qazi, I. M. and Khattak, I.A. (2007): Composition and adulteration analysis of milk samples. Sarhad Journal of Agriculture. 23(4): 1127. 
Barham, G.S.; Khaskheli, M.; Soomro, A.H. and Nizamani, Z.A. (2014a): Screening of adulterants and extent of added water in market milk at central zone of Sindh, Pakistan. IOSR Journal of Environmental Science, Toxicology and Food Technology. 8 (7): $77-$ 83.

Barham, G.S.; Khaskheli, M.; Soomro, A.H. and Nizamani, Z.A. (2014b): Detection and extent of extraneous water and adulteration in milk consumed at Hyderabad, Pakistan. Journal of Food and Nutrition Sciences. 2(2): 47-52.

Barham, G.S.; Khaskheli, M.; Soomro, A.H. and Nizamani, Z.A. (2015): Adulterated milk Used for consumption in Thatta District of Sindh, Pakistan. American Journal of Agricultural Science. 2(3): 91-96.

Batis, V.K.; Garg, S.K.; Chander, H. and Ranganathan, B. (1981): Indian Dairyman 33,435. Cited after Kamthania, M.; Saxena, J.; Saxena, K.; and Sharma, D.K. (2014): Milk adultration: Methods of detection and remedial measures. In national conference on synergetic trends in engineering and technology (STET) International Journal of Engineering and Technical Research ISSN (pp. 2321-0869).

Beall, D.P. and Scofield, H.R. (1995): Milk-Alkali Syndrome Associated with Calcium Carbonate Consumption: Report of 7 Patients with Parathyroid Hormone Levels and an Estimate of Prevalence Among Patients Hospitalized with Hypercalcemia. Medicine. 74(2): 89-96.

Bendale, V.T.; Patil, C.L.; Chavan, R.P. and Shinde, D.N. (2015): Analysis of milk quality \& adulteration in milk samples collected from Thane. International Journal of Pharma and Bio Sciences. 6(4):729-733.

Centre for Science and Environment (online) (2006): FSSAI Watch, Available from nationalsurvey-milk-adulteration, 2011.

Chanda, T.; Debnath, G.K.; Hossain, M.E.; Islam, M.A. and Begum, M.K. (2012): Adulteration of raw milk in the rural areas of Barisal district of Bangladesh. Bangladesh Journal of Animal Science. 41(2): 112-115.

Clare, D.A.; Catignani, G.L. and Swaisgood, H.E. (2003): Biodefense properties of milk: the role of antimicrobial proteins and peptides. Current pharmaceutical design. 9(16): 1239-1255.

Debnath, A.; Banerjee, S.; Rai, C. and Roy, A. (2015): Qualitative Detection of Adulterants in Milk Samples From Kolkata And Its Suburban Areas. Impact: Int. J. Res. Appl., Nat. Soc. Sci, 3(8): 81-88.

Debnath, G.K.; Kober, A.K.M.H.; Chanda, T.; Chanda, G.C. and Bari, M.S. (2014): A Comparative Study on the Quality of Available Brand and Non Brand Fluid Milk Consumed by the People of Chittagong City of
Bangladesh. International Journal of Natural Sciences. 4(1): 16-20.

Draaiyer, J.; Dugdill, B.; Bennett, A. and Mounsey, J. (2009): Milk testing and payment systems. Resource book: a practical guide to assist milk producer groups. Milk testing and payment systems. Resource book: a practical guide to assist milk producer groups.

Egyptian Standards (2005): Raw Milk Egyptian for Standardization. No. 154.

El-Bessary, M.M.A. (2006): Sanitary status of milk and some milk products marketed in suburbs of Assiut Governorate. Ph.D. Thesis, Fac .Vet. Med. Assiut, Uni. Egypt.

El-Loly, M.M.; Mansour, A.I.A. and Ahmed, R.O. (2013): Evaluation of Raw Milk for Common Commercial Additives and Heat Treatments. Internet Journal of Food Safety. 15, 7-10.

EL-Mossalami, H.H.A. (2014): Physicochemical differences between cooking and pasteurized butter sold in Alexandria city. Assiut Veterinary Medical Journal. 60 (140): 59-66s

FAD "Food and Agriculture Department" (2005): Quick methods for detection of adulterants/contaminants in common food products., Technical committee, 16/T (1631) C.

Fahmid, S.; Sajjad, A.; Khan, M.; Jamil, N. and Ali, J. (2016): Determination of chemical composition of milk marketed in Quetta, Pakistan. Int. J. Adv. Res. Biol. Sci, 3(5): 98103.

FAO (1977): Manual of Food Quality Control, 14/8, page 8 / I.S 1224 - (Pt I) -Determination of milk fat by Gerber method)

Faraz, A.; Lateef, M.; Mustafa, M.I.; Akhtar, P.; Yaqoob, M. and Rehman, S. (2013): Detection of adulteration, chemical composition and hygienic status of milk supplied to various canteens of educational institutes and public places in Faisalabad. J Animal Plant Sci, 23(1): 119-24.

Gapper, L.W.; Fong, B.Y.; Otter, D.E.; Indyk, H.E. and Woollard, D.C. (2004): Determination of nitrite and nitrate in dairy products by ion exchange LC with spectrophotometric detection. International Dairy Journal. 14(10): 881-887.

Genzebu, D.; Tamir, B. and Berhane, G. (2016): Physicochemical Properties of Raw Milk Collected from Different Value Chain Points in Central Ethiopia. World Journal of Dairy and Food Sciences. 11 (1): 88-94.

Gwin, M.C.; Lienert, G. and Kennedy, J. (2009): Formaldehyde exposure and asthma in children: a systematic review. Environmental health perspectives. 118(3): 313 .

Haasnoot, W.; Smits, N.G.; Kemmers-Voncken, A.E. and Bremer, M.G. (2004): Fast biosensor immunoassays for the detection of cows' milk 
in the milk of ewes and goats. Journal of Dairy Research. 71(3): 322-329.

Hallabo, S.A. and El-Nikeety, M.M. (1987): Comparative study between imported butter oil and Egyptian cow ghee [Egypt]. Egyptian Journal of Food Science (Egypt).15.

Harding, F. (1995): Milk quality. New York: Blackie Academic and Professional, an imprint of Chapman and Hall, Glasgow, UK, pp. 60-74, 157-15.

Hossain, M.B. and Dev., S.R. (2013): Physiochemical characteristics of various raw milk samples in a selected dairy plant of Bangladesh. International Journal of Engineering. 1(3): 2305-8269.

Hubbert, W.H.; Hagstad, H.V.; Spangler, E.; Hinton, M.H. and Hugher, K.L. (1996): Food Technol., milk processing. In: Food safety and Quality Assurance. 2nd Ed, Lowa State Univ. Ames. Press, USA pp. 93-100.

Ibrahim, A. (2006): Study on the quality of milk and some Egyptian dairy products, M.V.Sc. Thesis, Faculty of Agricultuer. Cairo University. Egypt.

Javaid, S.B.; Gadahi, J.A.; Khaskeli, M.; Bhutto, M.B.; Kumbher, S. and Panhwar, A.H. (2009): Physical and chemical quality of market milk sold at Tandojam, Pakistan. Pakistan Veterinary Journal.29 (1): 27-31

Kandpal, S.D.; Srivastava, A.K. and Negi, K.S. (2012): Estimation of quality of raw milk (open \& branded) by milk adulteration testing kit. Indian Journal of Community Health. 24(3): 188-192.

Kartheek, M.; Smith, A.A.; Muthu, A.K. and Manavalan, $R$. (2011): Determination of adulterants in food: a review. Journal of Chemical and Pharmaceutical Research. 3(2), 629-636.

Kehar, N.D. (1956): Studies on fats, oils and vanaspatis. Indian Journal of Medical Research; New Delhi.

Khalid, A. (2006): Milk production in Sudan (conference) Kh Sudan, pp.: 1-3. Shojaei Z.A. and Yadollahi A. (2008): Physicochemical and Microbiological Quality of Raw Pasteurized and UHT Milks in Shops. Asian Journal of Scientific Research. 1: 532-538.

Knothe, G. (2002): Structure indices in FA chemistry. How relevant is the iodine value. Journal of the American Oil Chemists' Society. 79(9): 847-854.

Kumar, A.; LAL, D.; Seth, R. and Sharma, R. (2002): Recent trends in detection of adulteration in milk fat: A review. Indian journal of dairy science. 55(6): 319-330.

Kumar, R.; Singh, D.K. and Chawla, N.K. (1998): Adulteration / Contamination of Milk Demystified. Indian Dairyman 50: 25-33

Lampert, L.M. (1975): Modern Dairy Products. 3rd Ed., Chemical Publishing Co., Inc., New York.
Lateef, M.; Faraz, A.; Mustafa, M. I.; Akhtar, P. and Bashir, M.K. (2009): Detection of adulterants and chemical composition of milk supplied to canteens of various hospitals in Faisalabad city. Pak. J. Zoo, 1 (9):139-142.

Ling, T.R. (1963): Textbook of dairy chemistry. Vol. II, 3rd Ed, P.I. 30, Chapman and Hall, London. Mansour, A.I.A.; El-Loly, M.M. and Ahmed, R.O. (2012): A preliminary detection of physical and chemical properties, inhibitory substances and preservatives in raw milk. Internet Journal of Food Safety. 14:93-103.

Moore, J.C.; Spink, J. and Lipp, M. (2012): Development and application of a database of food ingredient fraud and economically motivated adulteration from 1980 to 2010. Journal of Food Science. 77(4):119-126.

Mota, F.J.; Ferreira, I. M.; Cunha, S.C.; Beatriz, M. and Oliveira, P.P. (2003): Optimisation of extraction procedures for analysis of benzoic and sorbic acids in foodstuffs. Food Chemistry. 82(3): 469-473.

Mudgil, D. (2008): Detection of adulteration in milk. M.V.Sc. Thesis, India.

Nickerson, S.C. (1995): Milk Production: Factors affecting milk composition. In: Milk Quality. 1st Ed, F. Harding, Blackie Academic and Professional, Chapman and Hall, London, New York, Tokyo, Madras.

Nirwal, S.; Pant, R. and Rai, N. (2013): Analysis of milk quality, adulteration and mastitis in milk samples collected from different regions of Dehradun. International Journal of pharmtech Research.5 (2): 359-364.

Panda, D. and Bindla, M.P. (1998): Detection of Adulteration In Ghee With Animal Body Fats And Vegetable Oils Using Opacity Test. J. Dairying Foods and Home Sci, 17:31-36.

Park, Y.W.; Juárez, M.; Ramos, M. and Haenlein, G.F.W. (2007): Physico-chemical characteristics of goat and sheep milk. Small ruminant research. 68(1): 88-113.

Parmar, S.K. (2005): Evaluation of quality of market ghee. M.V.Sc. Thesis, NDRI, Karnal. India.

Pien, J.; Desirant, J. and Iafontaine, D. (1953): Detection of hydrogen peroxide in milk. Ann. Falsif, Fraudes, Paris, Dairy Sci. Abst, 46:539/540, 416-426.

Prodhan, U.K.; Alam, M.J.; Sadia, M.K.; Sultana, S.; Hye, M.A. and Ahamed, M.S. (2016): Study on the quality of commercial market milk available in Bangladesh. Annals. Food science and technology .17 (2): 293-298.

Rangappa, K.S. and Achaya, K.T. (1974): Indian dairy products. Asia Publishing House.

Rao, L.V.; Ranganadham, M. and Rao, B.V.R. (2004): Quality of milk and milk products marketed in hyderabad city. Part II: Chemical quality of milk products. Indian journal of dairy science. 57(3): 171-176. 
Recio, I. and Olieman, C. (1996): Determination of denatured serum proteins in the casein fraction of heat-treated milk by capillary zone electrophoresis. Electrophoresis. 17(7): 12281233.

Renny, E.F.; Daniel, D.K.; Krastanov, A.I.; Zachariah, C.A. and Elizabeth, R. (2005): Enzyme based sensor for detection of urea in milk. Biotechnology and Biotechnological Equipment. 19(2): 198-201.

Rideout, T.C.; Liu, Q.; Wood, P. and Fan, M.Z. (2008): Nutrient utilisation and intestinal fermentation are differentially affected by the consumption of resistant starch varieties and conventional fibres in pigs. British Journal of Nutrition. 99(5): 984-992.

Saad, B.; Bari, M.F.; Saleh, M.I.; Ahmad, K. and Talib, M.K.M. (2005): Simultaneous determination of preservatives (benzoic acid, sorbic acid, methylparaben and propylparaben) in foodstuffs using high-performance liquid chromatography. Journal of Chromatography A, 1073(1): 393-397.

Sagdic, O.; Donmez, M. and Demirci, M. (2004): Comparison of characteristics and fatty acid profiles of traditional Turkish yayik butters produced from goats', ewes' or cows' milk. Food Control. 15(6): 485-490.

Santos, P.M.; Pereira, E.R. and Rodrigyez- Saona, L.E. (2013): Rapid detection and quantification of milk adulteration using infrared micro spectroscopy and chemometrics analysis. Food Chemistry. 138(1): 19-24.

See, A.S.; Salleh, A.B.; Bakar, F.A.; Yusof, N.A.; Abdulamir, A.S. and Heng, L.Y. (2010): Risk and health effect of boric acid. Am. J. Applied Sci., 7: 620-627.

Shaikh, N.; Soomro, A.H.; Sheikh, S.A. and Khaskheli, M. (2013): Extent of water adulteration and its influence on physical characteristics of market milk. Pakistan Journal of Nutrition.12 (2): 178.

Sharma, R.S.R. and Barui, A.K. (2011): Rapid Methods for Detection of Adulterants in Milk Chemical analysis of value added dairy products and their quality assurance. National Dairy Research Institute.

Singhal, O.P. (1980): Adulterants and methods for detection. Indian dairyman. 32(10): 771-774.

Singuluri, H. and Sukumaran, M.K. (2014): Milk adulteration in Hyderabad, India-a comparative study on the levels of different adulterants present in milk. Journal of Chromatography and Separation Techniques. 5(1): 1-3.

SobeihAzza, M.K. (2000): Studies on raw milk quality in Kaft El-Sheikh. M.V.Sc., Thesis, Fac. Vet.
Med., Kafr El-Sheikh Branch, Tanta University. Egypt.

Soomro, A.A.; Khaskheli, M.; Memon, M.A.; Barham, G.S.; Haq, I.U.; Fazlani, S.N.; Khan, I.A.; Lochi, G.M. and Soomro, R.N. (2014): Study on adulteration and composition of milk sold at Badin. International Journal of Research in applied natural and Social Sciences. 2(9): 57-70.

Souza, S.S.; Cruz, A.G.; Walter, E.H.; Faria, J.A.; Celeghini, R.M.; Ferreira, M.M. and Sant'Ana, A.D.S. (2011): Monitoring the authenticity of Brazilian UHT milk: A chemometricapproach. Foodchemistry. 124(2): 692-695.

Standard, I. (1966): Method of sampling and test for cream (Reference method). Bureau of Indian Standards, IS-3509, Manak Bhavan, New Delhi: BIS.

Standard, I. (1997): Milk, cream and evaporated milk-determination of total solid content (Reference method). Bureau of Indian Standards, IS-12333, Manak Bhavan, New Delhi: BIS.

Stokes, A.W. (1897): The detection of gelatin in cream. Analyst, 22(December), 320a-320a.

Swathi, J.K. and Kauser, N. (2015): A study on adulteration of milk and milk products from local vendors. International Journal of Biomedical and Advance Research. 6 (9): 678681.

Tanmay, H.; Vivek, S.; Priti, S. and Parmar, M.K.P. (2017): "Physico-chemical properties analysis of ghee" International Journal of science enviromental technology. 6(1): 899.

Tariq, M.A. (2001): Subject: A close look at dietary patterns. http://www. dawn. com/2001/11/05/ ebr13. Htm. Accessed Feb,2011.

Tipu, M.S.; Altaf, I.; Ashfaq, M. and Siddique, S. (2007): Monitoring of chemical adulterants and hygienic status of market milk. Handbook published by Quality Control Laboratory, Univ. Vet. Anim. Sci., Lahore, Pakistan. pp, 7.

Uddin, M.S.; Habib, M.R.; Islam, M.A.; Afrin, S. and Rashid, M.H. (2016): Quality of raw milk collected from Mymensingh town in Bangladesh. Bangladesh Journal of Animal Science. 45(2): 73-78.

Wahba, N.M. and Korashy, E.A. (2006): A preliminary detection of inhibitory substances in milk sold in Assiut Governorate. Assiut Vet. Med. J, 52(109): 93-100.

Zhang, L.; Wu, L.L.; Wang, Y.P.; Liu, A.M.; Zou, C.C. and Zhao, Z.Y. (2009): Melaminecontaminated milk products induced urinary tract calculi in children. World Journal of Pediatrics. 5(1): 31-35. 


\section{الكثف عن الغش في اللبن وبعض منتجات الألبان \\ سعدية حلمي الشناوي ، عادل مصطفي الخولهي ، محد معروف علي زينهم ، الاء بحي جابر \\ E-mail: vet.alaayehya@gmail.com Assiut University web-site: www.aun.edu.eg}

الغش في الأغذية عن طريق خلط أو استبدال أو إز الة بعض المكونات التي لا تقدر بثمن من المنتج الغذائي بالمواد الرديئة هو وسيله

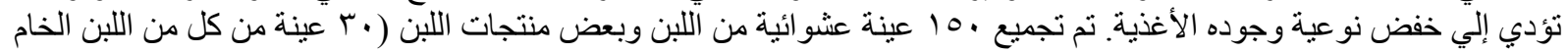

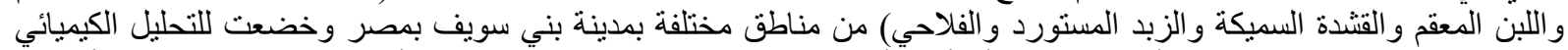

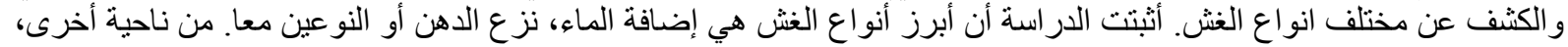

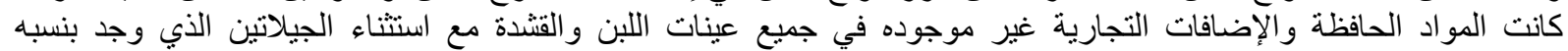

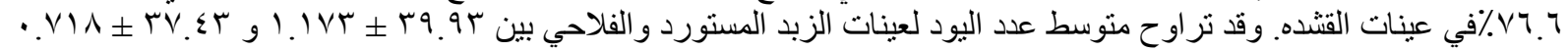

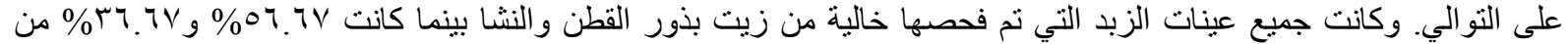

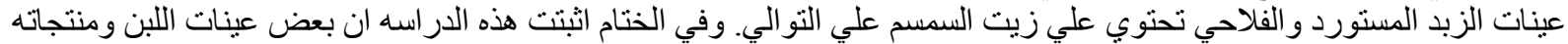

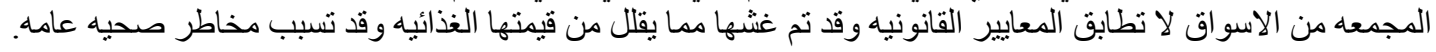

